\title{
Phytosociology of the arboreal component in an area of springs, Pernambuco
}

\author{
Roseane Karla Soares da Silva' \\ Ana Lícia Patriota Feliciano" \\ Luiz Carlos Marngon"' \\ Rosval Barros de Andrade Limaiv \\ Fernando José Freirev
}

\section{Abstract}

This study aimed to know the phytosociological composition of the arboreal component in an area of springs in Sirinhaém - PE. Ten plots $(10 \mathrm{~m} \times 25 \mathrm{~m})$ were arranged in rays above the springs and distributed systematically in 5 lines, separated by a $45^{\circ}$ angle, each. In each line, 2 plots were allocated, at an interdistance of $25 \mathrm{~m}$. In each plot, all individuals with CAP $\geq 15 \mathrm{~cm}$ were sampled, which were measured and had the estimated height. The phytosociological parameters were analyzed and an admissible sampling error of $20 \%$ and probability level of $95 \%$ was adopted. The calculated sampling error was $18 \%$, lower than that established. The springs had a density of 1,236 individuals ha-1, with an estimated basal area of $27,647 \mathrm{~m}^{2} \mathrm{ha}^{-1}$. Tapirira guianensis was characterized by a combination of large numbers of individuals, high dominance and high frequency, demonstrating that it is a species with wide distribution in the area. Regarding the relative frequency, in addition to T. guianensis, Eschweilera ovata and Inga flagelliformis were distinguished. The highest values of absolute dominance were of the species T. guianensis and Virola gardneri. In terms of Importance Value, the highlight was on T. guianensis and V. gardneri.

Keywords: Floristics; Preservation; Atlantic forest

\footnotetext{
' Universidade Federal Rural de Pernambuco-Recife-Pernambuco - Brasil. E-mail: roseanekarla.floresta@gmail.com

" Universidade Federal Rural de Pernambuco-Recife-Pernambuco - Brasil. E-mail:ana.feliciano@ufrpe.br

III Universidade Federal Rural de Pernambuco-Recife-Pernambuco- Brasil. E-mail: luiz.marangon@ufrpe.br

Iv Universidade Federal Rural de Pernambuco-Recife-Pernambuco-Brasil.E-mail: rosival_barros@yahoo.com.br

v Universidade Federal Rural de Pernambuco-Recife-Pernambuco-Brasil. E-mail: fernando@ufrpe.br
} 


\section{Introduction}

The term springs is defined by the Forestry Code, Law no 12.651, of May 25, 2012, as a natural outcrop of the water table that presents perenniality and starts a watercourse, forming part of the Permanent Preservation Area (PPA). A minimum radius of 50 meters wide must be preserved around the Springs, but if the area is considered consolidated, ie with anthropic occupation pre-existing before July 22, 2008, the minimum mandatory radius for preservation is only 15 meters, assuming the maintenance of agroforestry activities, ecotourism or rural tourism (BRASIL, 2012).

The characteristics of a springs can be influenced by several factors, such as climate, vegetation cover, topography, geology, as well as type, use and management of the soil of the area in which the source is located. They are characterized as the place where a water course begins (river, stream), independently of the dimensions (LOZINSKI et al., 2010).

According to Oliveira et al. (2012), despite the environmental importance and legal protection, springs $s$ continue to be degraded and the reduction of ciliary vegetation in these areas cause a significant increase in soil erosion processes, with losses of regional hydrology, reduction of biodiversity and degradation of large areas.

Preserving the forest cover in the surroundings of these environments, has become a necessity, therefore, according to Balbinot et al. (2008) the flow of water in areas with full forest cover is more stable and sustainable than in other cases. For Oliveira and Amaral (2004), floristic and phytosociological studies are essential for the conservation of diversity, since they provide the knowledge of the current state of the fragments and subsidies for their recovery plans.

In this sense, this work aimed to know the phytosociological composition of the arboreal component of the vegetation occurring in the Springs area, located in Córrego do Campo, which flows into the Sirinhaém River, in the municipality of Sirinhaém - PE, to promote restoration and preservation of these environments.

\section{Materials and methods}

\section{Study area}

The study was carried out in the springs of Córrego do Campo, which flows into the Sirinhaém River, located in the Engenho Buranhém, belonging to Usina Trapiche S / $\mathrm{A}$, in the Municipality of Sirinhaém, Pernambuco, under coordinates $8^{\circ} 34^{\prime} 38^{\prime \prime} \mathrm{S}$ and $35^{\circ} 10^{\prime} 4.9^{\prime}$ ' 'W. The area studied has an average altitude of $75 \mathrm{~m}$ and the forest is classified according to the IBGE (2012) as Lowland Rain Forest (Figure 1). According to Köppen's classification, the region presents an Am monsoon climate type (ALVARES et al., 2013), with an annual average temperature of $25.6^{\circ} \mathrm{C}$ and precipitation around $1,800 \mathrm{~mm}$. Soils found in the region are of the Yellow Latosol type; Yellow Argisol; Red-Yellow and Greyish; Gleissolo; Cambissolo and Neosolos Flúvios (SANTOS et al., 2013).

\subsection{Collection of data}

For the data collection of the arboreal component, 10 plots measuring $10 \mathrm{~m}$ x $25 \mathrm{~m}$ were arranged in rays, above the springs and distributed systematically in 5 lines, separated by $45^{\circ}$ angle, each. In each line, 2 plots were allocated, separated by a distance of $25 \mathrm{~m}$.

The sample units were geo-referenced with the aid of a GPS (Global Positioning System) receiver, model Garmim - V. In each plot, all individuals with Chest Height Circumference (CAP) $\geq 15 \mathrm{~cm}$ were sampled, which were tagged and enumerated progressively with PVC plaques $(5 \mathrm{~cm} \times 5 \mathrm{~cm})$. Each tree sampled had the CAP measured with tape, and the estimated height with modules $(1.5 \mathrm{~m}$ each) of high pruning shears.

The individuals sampled had the botanical material collected, labeled and subjected to oven drying $\left(65^{\circ} \mathrm{C}\right)$ for 48 hours. The identification was carried out by comparison with samples belonging to the Herbarium Dárdano de Andrade Lima of the Agronomic Institute of Pernambuco (IPA), where the fertile material was deposited, as well as by consulting specialists and specialized literature. The identification followed the classification system APG IV (Angiosperm Phylogeny Group) (APG IV, 2016) and the botanical nomenclature and their respective authors were obtained from the Flora of Brazil website (http:// floradobrasil.jbrj.gov.br).

\section{Data analysis}

This study utilized phytosociological parameters such as Absolute Density (DA), Relative Density (DR), Absolute Frequency (FA), Relative Frequency (FR), Absolute Dominance (DoA), Relative Dominance (DoR), Coverage Value of Importance (VI), according to Mueller-Dombois and Ellenberg (1974).

In this work an acceptable sampling error (E\%) of $20 \%$ and probability level of $95 \%$ were adopted. The sampling error was obtained by the following expression (SOARES; PAULA NETO; SOUZA, 2007):

$$
E \%= \pm \frac{S_{\Gamma} . t}{\bar{Y}} .100
$$

Where: $S_{\bar{Y}}=$ standard error of the mean; $\mathrm{t}=$ tabulated value of Student's t distribution ( $\alpha 5 \%, \mathrm{n}-1 \mathrm{gl})$; and $\bar{Y}=$ mean number of trees per plot.

\section{Results and discussion}

For the conditions under which the work was performed, it was found that the number of sample units utilized was sufficient to meet the admissible sampling error of $20 \%$, at $95 \%$ probability. The calculated sampling error, taking into account the number of individuals per plot was $18 \%$, which is lower than the established value. 
Figure 1 - Photograph of the Buranhém Plant, Trapiche S/A Plant, Sirinhaém / PE, with detail of the Lowland Rain Forest fragment and data collection point (Source: Usina Trapiche S/A)

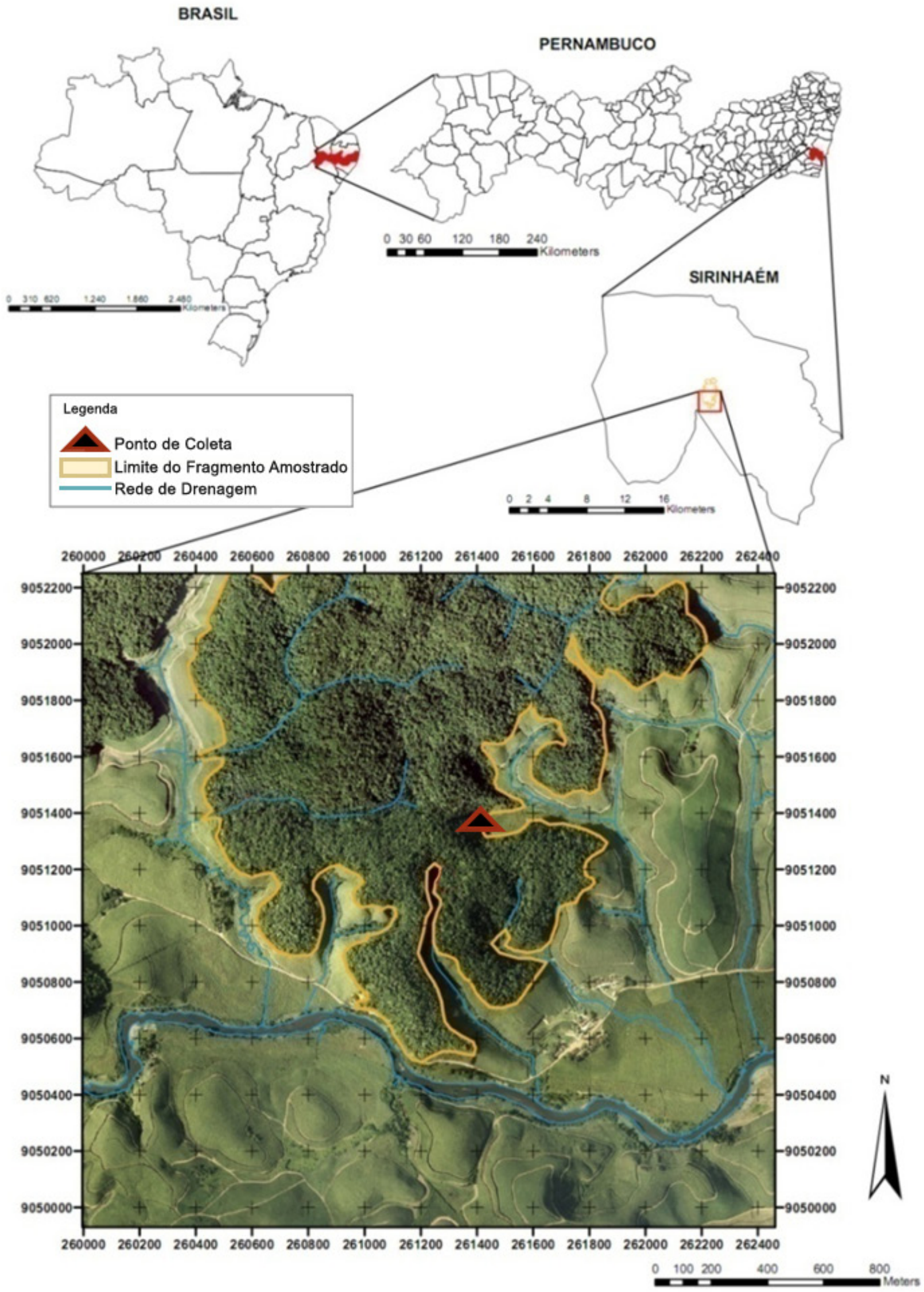


Table 1 - Phytosociological parameters of the species sampled at the springs of Córrego do Campo, Mata do Engenho Buranhém, in the municipality of Sirinhaém, Pernambuco, in descending order of importance (VI). In which: Ni - Number of individuals of species i; DA - Absolute density (ind. ha-1); DR - Relative density (\%); FA - Absolute frequency (\%); FR - Relative frequency (\%); DoA - Absolute dominance $\left(\mathrm{m}^{2} \mathrm{ha}^{-1}\right)$; DoR - Relative dominance; VC - Value of coverage and VI - Value of importance.

\begin{tabular}{|c|c|c|c|c|c|c|c|c|c|}
\hline Species & $\mathrm{Ni}$ & DA & DR & FA & FR & DoA & DoR & $\mathrm{VI}$ & VC \\
\hline Tapirira guianensis Aubl. & 33 & 132 & 10.68 & 70 & 4.79 & 5.142 & 18.60 & 34.07 & 29.28 \\
\hline Virola gardneri (A. DC.) Warb. & 7 & 28 & 2.27 & 50 & 3.42 & 3.135 & 11.34 & 17.03 & 13.61 \\
\hline Protium heptaphyllum (Aubl.) Marchand & 20 & 80 & 6.47 & 60 & 4.11 & 1.568 & 5.67 & 16.25 & 12.14 \\
\hline Inga flagelliformis (Vell.) Mart. & 21 & 84 & 6.80 & 70 & 4.79 & 0.970 & 3.51 & 15.10 & 10.30 \\
\hline Eschweilera ovata (Cambess.) Miers & 16 & 64 & 5.18 & 80 & 5.48 & 0.905 & 3.27 & 13.93 & 8.45 \\
\hline $\begin{array}{l}\text { Schefflera morototoni (Aubl.) Maguire, Steyerm. } \\
\& \text { Frodin }\end{array}$ & 18 & 72 & 5.83 & 50 & 3.42 & 1.281 & 4.63 & 13.88 & 10.46 \\
\hline Eschweilera ovata (Cambess.) Miers & 16 & 64 & 5.18 & 80 & 5.48 & 0.905 & 3.27 & 13.93 & 8.45 \\
\hline $\begin{array}{l}\text { Schefflera morototoni (Aubl.) Maguire, Steyerm. } \\
\& \text { Frodin }\end{array}$ & 18 & 72 & 5.83 & 50 & 3.42 & 1.281 & 4.63 & 13.88 & 10.46 \\
\hline Mabea occidentalis Benth. & 20 & 80 & 6.47 & 50 & 3.42 & 0.966 & 3.49 & 13.39 & 9.97 \\
\hline Parkia pendula (Willd.) Benth. ex Walp. & 4 & 16 & 1.29 & 30 & 2.05 & 2.735 & 9.89 & 13.24 & 11.19 \\
\hline Annona montana Macfad. & 12 & 48 & 3.88 & 70 & 4.79 & 1.191 & 4.31 & 12.99 & 8.19 \\
\hline Miconia minutiflora (Bonpl.) DC. & 11 & 44 & 3.56 & 60 & 4.11 & 0.460 & 1.67 & 9.33 & 5.23 \\
\hline Guatteria pogonopus Mart. & 17 & 68 & 5.50 & 40 & 2.74 & 0.173 & 0.62 & 8.87 & 6.13 \\
\hline Dialium guianense (Aubl.) Sandwith & 7 & 28 & 2.27 & 30 & 2.05 & 0.937 & 3.39 & 7.71 & 5.65 \\
\hline Simarouba amara Aubl. & 3 & 12 & 0.97 & 30 & 2.05 & 1.281 & 4.63 & 7.66 & 5.60 \\
\hline Pouteria sp. & 8 & 32 & 2.59 & 40 & 2.74 & 0.614 & 2.22 & 7.55 & 4.81 \\
\hline Thyrsodium spruceanum Benth. & 8 & 32 & 2.59 & 50 & 3.42 & 0.208 & 0.75 & 6.77 & 3.34 \\
\hline Miconia prasina (Sw.) DC. & 9 & 36 & 2.91 & 30 & 2.05 & 0.307 & 1.11 & 6.08 & 4.02 \\
\hline Nectandra cuspidata Nees \& Mart. & 3 & 12 & 0.97 & 20 & 1.37 & 0.999 & 3.61 & 5.96 & 4.59 \\
\hline Miconia holosericea (L.) DC. & 7 & 28 & 2.27 & 40 & 2.74 & 0.157 & 0.57 & 5.57 & 2.84 \\
\hline Coussarea sp. & 4 & 16 & 1.29 & 30 & 2.05 & 0.353 & 1.28 & 4.63 & 2.57 \\
\hline Myrcia fallax (Rich.) DC. & 4 & 16 & 1.29 & 40 & 2.74 & 0.097 & 0.35 & 4.38 & 1.64 \\
\hline Rheedia brasiliensis (Mart.) Planch. \& Triana & 6 & 24 & 1.94 & 30 & 2.05 & 0.075 & 0.27 & 4.27 & 2.21 \\
\hline Cupania oblongifolia Mart. & 1 & 4 & 0.32 & 10 & 0.68 & 0.765 & 2.77 & 3.77 & 3.09 \\
\hline Tovomita brevistaminea Engl. & 5 & 20 & 1.62 & 20 & 1.37 & 0.193 & 0.70 & 3.69 & 2.32 \\
\hline Himatanthus phagedaenicus (Mart.) Woodson & 3 & 12 & 0.97 & 30 & 2.05 & 0.169 & 0.61 & 3.64 & 1.58 \\
\hline Siparuna guianensis Aubl. & 4 & 16 & 1.29 & 20 & 1.37 & 0.254 & 0.92 & 3.58 & 2.21 \\
\hline Miconia falconi Brade & 5 & 20 & 1.62 & 20 & 1.37 & 0.089 & 0.32 & 3.31 & 1.94 \\
\hline Guazuma ulmifolia Lam. & 5 & 20 & 1.62 & 10 & 0.68 & 0.185 & 0.67 & 2.97 & 2.29 \\
\hline Pera ferruginea Mull. Arg. & 3 & 12 & 0.97 & 20 & 1.37 & 0.128 & 0.46 & 2.81 & 1.44 \\
\hline Protium giganteum Engl. & 3 & 12 & 0.97 & 20 & 1.37 & 0.120 & 0.44 & 2.78 & 1.41 \\
\hline Henriettea succosa (Aubl.) DC. & 2 & 8 & 0.65 & 20 & 1.37 & 0.166 & 0.60 & 2.62 & 1.25 \\
\hline Vismia guianensis (Aubl.) Choisy & 3 & 12 & 0.97 & 20 & 1.37 & 0.067 & 0.24 & 2.58 & 1.21 \\
\hline Psychotria cf. platypoda DC. & 5 & 20 & 1.62 & 10 & 0.68 & 0.058 & 0.21 & 2.51 & 1.83 \\
\hline Helicostylis tomentosa (Poepp. \& Endl.) Rusby & 3 & 12 & 0.97 & 20 & 1.37 & 0.031 & 0.11 & 2.45 & 1.08 \\
\hline Cupania racemosa (Vell.) Radlk. & 2 & 8 & 0.65 & 20 & 1.37 & 0.111 & 0.40 & 2.42 & 1.05 \\
\hline Symphonia globulifera L.f. & 1 & 4 & 0.32 & 10 & 0.68 & 0.331 & 1.20 & 2.21 & 1.52 \\
\hline Pogonophora schomburgkiana Miers ex Benth. & 2 & 8 & 0.65 & 20 & 1.37 & 0.015 & 0.06 & 2.07 & 0.70 \\
\hline Bowdichia virgilioides Kunth & 1 & 4 & 0.32 & 10 & 0.68 & 0.258 & 0.93 & 1.94 & 1.26 \\
\hline Byrsonima sp. & 1 & 4 & 0.32 & 10 & 0.68 & 0.165 & 0.60 & 1.61 & 0.92 \\
\hline Macrosamanea pedicellaris (DC.) Kleinhoonte & 2 & 8 & 0.65 & 10 & 0.68 & 0.047 & 0.17 & 1.50 & 0.82 \\
\hline Cecropia pachystachya Trécul & 1 & 4 & 0.32 & 10 & 0.68 & 0.130 & 0.47 & 1.48 & 0.80 \\
\hline Indeterminada 1 & 1 & 4 & 0.32 & 10 & 0.68 & 0.126 & 0.46 & 1.47 & 0.78 \\
\hline Swartzia pickelii Killip ex Ducke & 2 & 8 & 0.65 & 10 & 0.68 & 0.034 & 0.12 & 1.46 & 0.77 \\
\hline Inga sp. & 1 & 4 & 0.32 & 10 & 0.68 & 0.118 & 0.43 & 1.44 & 0.75 \\
\hline Indeterminada 3 & 1 & 4 & 0.32 & 10 & 0.68 & 0.076 & 0.28 & 1.28 & 0.60 \\
\hline Rubiaceae 1 & 1 & 4 & 0.32 & 10 & 0.68 & 0.067 & 0.24 & 1.25 & 0.57 \\
\hline Plathymenia foliolosa Benth. & 1 & 4 & 0.32 & 10 & 0.68 & 0.056 & 0.20 & 1.21 & 0.53 \\
\hline
\end{tabular}


continuation table $1 \ldots$

\begin{tabular}{|c|c|c|c|c|c|c|c|c|c|}
\hline Species & $\mathrm{Ni}$ & DA & DR & FA & FR & DoA & DoR & VI & VC \\
\hline Guapira opposita (Vell.) Reitz & 1 & 4 & 0.32 & 10 & 0.68 & 0.046 & 0.17 & 1.17 & 0.49 \\
\hline Andira nitida Mart. ex Benth. & 1 & 4 & 0.32 & 10 & 0.68 & 0.044 & 0.16 & 1.17 & 0.48 \\
\hline Ocoteasp. & 1 & 4 & 0.32 & 10 & 0.68 & 0.041 & 0.15 & 1.16 & 0.47 \\
\hline Anaxagorea dolichocarpa Sprague \& Sandwith & 1 & 4 & 0.32 & 10 & 0.68 & 0.126 & 0.46 & 1.47 & 0.78 \\
\hline Inga sp. & 1 & 4 & 0.32 & 10 & 0.68 & 0.118 & 0.43 & 1.44 & 0.75 \\
\hline Indeterminada 4 & 2 & 8 & 0.65 & 10 & 0.68 & 0.034 & 0.12 & 1.46 & 0.77 \\
\hline Indeterminada 2 & 1 & 4 & 0.32 & 10 & 0.68 & 0.076 & 0.28 & 1.28 & 0.60 \\
\hline Rubiaceae 1 & 1 & 4 & 0.32 & 10 & 0.68 & 0.067 & 0.24 & 1.25 & 0.57 \\
\hline Plathymenia foliolosa Benth. & 1 & 4 & 0.32 & 10 & 0.68 & 0.056 & 0.20 & 1.21 & 0.53 \\
\hline Guapira opposita (Vell.) Reitz & 1 & 4 & 0.32 & 10 & 0.68 & 0.046 & 0.17 & 1.17 & 0.49 \\
\hline Andira nitida Mart. ex Benth. & 1 & 4 & 0.32 & 10 & 0.68 & 0.044 & 0.16 & 1.17 & 0.48 \\
\hline Ocotea sp. & 1 & 4 & 0.32 & 10 & 0.68 & 0.041 & 0.15 & 1.16 & 0.47 \\
\hline Ocotea cf. gardneri (Meisn.) Mez & 1 & 4 & 0.32 & 10 & 0.68 & 0.037 & 0.13 & 1.14 & 0.46 \\
\hline Inga thibaudiana DC. & 1 & 4 & 0.32 & 10 & 0.68 & 0.031 & 0.11 & 1.12 & 0.43 \\
\hline Myrtaceae 1 & 1 & 4 & 0.32 & 10 & 0.68 & 0.031 & 0.11 & 1.12 & 0.43 \\
\hline Sloanea sp. & 1 & 4 & 0.32 & 10 & 0.68 & 0.029 & 0.10 & 1.11 & 0.43 \\
\hline Brosimum guianense (Aubl.) Huber & 1 & 4 & 0.32 & 10 & 0.68 & 0.027 & 0.10 & 1.11 & 0.42 \\
\hline Dipteryx odorata (Aubl.) Willd. & 1 & 4 & 0.32 & 10 & 0.68 & 0.017 & 0.06 & 1.07 & 0.38 \\
\hline Lauraceae 1 & 1 & 4 & 0.32 & 10 & 0.68 & 0.014 & 0.05 & 1.06 & 0.37 \\
\hline Gustavia augusta L. & 1 & 4 & 0.32 & 10 & 0.68 & 0.008 & 0.03 & 1.04 & 0.35 \\
\hline Syzygium malaccense (L.) Merr. \& L.M. Perry & 1 & 4 & 0.32 & 10 & 0.68 & 0.008 & 0.03 & 1.04 & 0.35 \\
\hline
\end{tabular}

The studied springs had a density of 1.236 individuals ha- ${ }^{-1}$, with an estimated basal area of $27.647 \mathrm{~m}^{2} \mathrm{ha}^{-1}$. Table 1 presents the analysis of the phytosociological parameters of the springs.

The species that presented the highest values of density were: Tapirira guianensis, Inga flagelliformis, Protium heptaphyllum, Mabea occidentalis and Schefflera morototoni (Table 1). It was verified that $38 \%$ of the species found in the springs of Córrego do Campo presented only one individual, being considered by Oliveira et al. (2008) as "locally rare". These species, according to Scariot et al. (2003), are likely to experience a rapid decline in population terms, tending to local extinction. However, this consideration should be made only for the study area, without generalizations, because, the question of the rarity of a species may be associated with the sampling procedure or variations in the geographical distribution (SILVA; PRATA; MELLO, 2016).

The pioneer species $T$. guianensis was characterized by the combination of a large number of individuals (33), high dominance $\left(5.142 \mathrm{~m}^{2} \mathrm{ha}^{-1}\right)$, and high frequency, present in $70 \%$ of the plots, showing a species with a wide distribution in the area. In Mata de Caldeiras, in Catende, Mata Sul of Pernambuco, T. guianensis recorded the highest values of density, frequency and dominance (COSTA JÚNIOR et al., 2008). According to Lopes et al. (2016), the species present a high percentage of natural regeneration.

In the study by Pinto et al. (2005) on the distribution of arboreal-shrub species along the soil moisture gradients from the basins of the Santa Cruz river basin in Lavras, Minas Gerais, T. guianensis and P. heptaphyllum were the most abundant, both in environments with well-drained soils. With this, it can be inferred that these species are well adapted to local conditions.

Regarding the relative frequency, in addition to $T$. guianensis $(4.79 \%)$, the most outstanding species, in descending order of values were: Eschweilera ovata (5.48\%); Inga flagelliformis (4.79), Annona montana (4.79); Protium heptaphyllum (4.11\%) and Miconia minutiflora (4.11\%); Mabea occidentalis (3.42\%), Schefflera morototoni (3.42\%), Thyrsodium spruceanum (3.42\%) and Virola gardneri (3.42\%) (Table 1). These species are well distributed in the sampled area, with absolute frequency greater than or equal to $50 \%$.

The highest values of absolute dominance (DoA) in the analyzed area were of the species T. guianensis $\left(5.142 \mathrm{~m}^{2}\right.$ $\left.\mathrm{ha}^{-1}\right)$, Virola gardneri $\left(3.135 \mathrm{~m}^{2} \mathrm{ha}^{-1}\right)$, Parkia pendula $(2.735$ $\left.\mathrm{m}^{2} \mathrm{ha}^{-1}\right)$, Protium heptaphyllum $\left(1.568 \mathrm{~m}^{2} \mathrm{ha}^{-1}\right)$, Simarouba amara $\left(1.281 \mathrm{~m}^{2} \mathrm{ha}^{-1}\right)$, Schefflera morototoni $\left(1.281 \mathrm{~m}^{2}\right.$ ha 1), Annona montana $\left(1.191 \mathrm{~m}^{2} \mathrm{ha}^{-1}\right)$, Nectandra cuspidata $\left(0.999 \mathrm{~m}^{2} \mathrm{ha}^{-1}\right)$, Inga flagelliformis $\left(0.970 \mathrm{~m}^{2} \mathrm{ha}^{-1}\right)$ and Mabea occidentalis $\left(0.966 \mathrm{~m}^{2} \mathrm{ha}^{-1}\right)$. Relative dominance values are shown in Figure 2.

These results are similar to those found by Costa Júnior et al. (2008) and Teixeira et al. (2010), in floristic studies carried out in the southern Brazilian forest of Pernambuco, which highlighted among the dominant species: Tapirira guianensis, Parkia pendula, Schefflera morototoni and Simarouba amara.

The 10 most important species in the community in terms of Importance Value (VI), ordered in descending order, were: Tapirira guianensis, Virola gardneri, Protium heptaphyllum, Inga flagelliformis, Eschweilera ovata, Schefflera morototoni, Mabea occidentalis, Parkia pendula, Annona montana and Miconia minutiflora. These species represented about $53.07 \%$ of the VI of the species sampled (Figure 3). It is worth mentioning that $70 \%$ of these species are from the beginning of succession (pioneers 
Figure 2 - Species with higher relative dominance (DoR), sampled at the springs s of the Córrego do Campo, Mata do Engenho Buranhém, in the municipality of Sirinhaém, Pernambuco

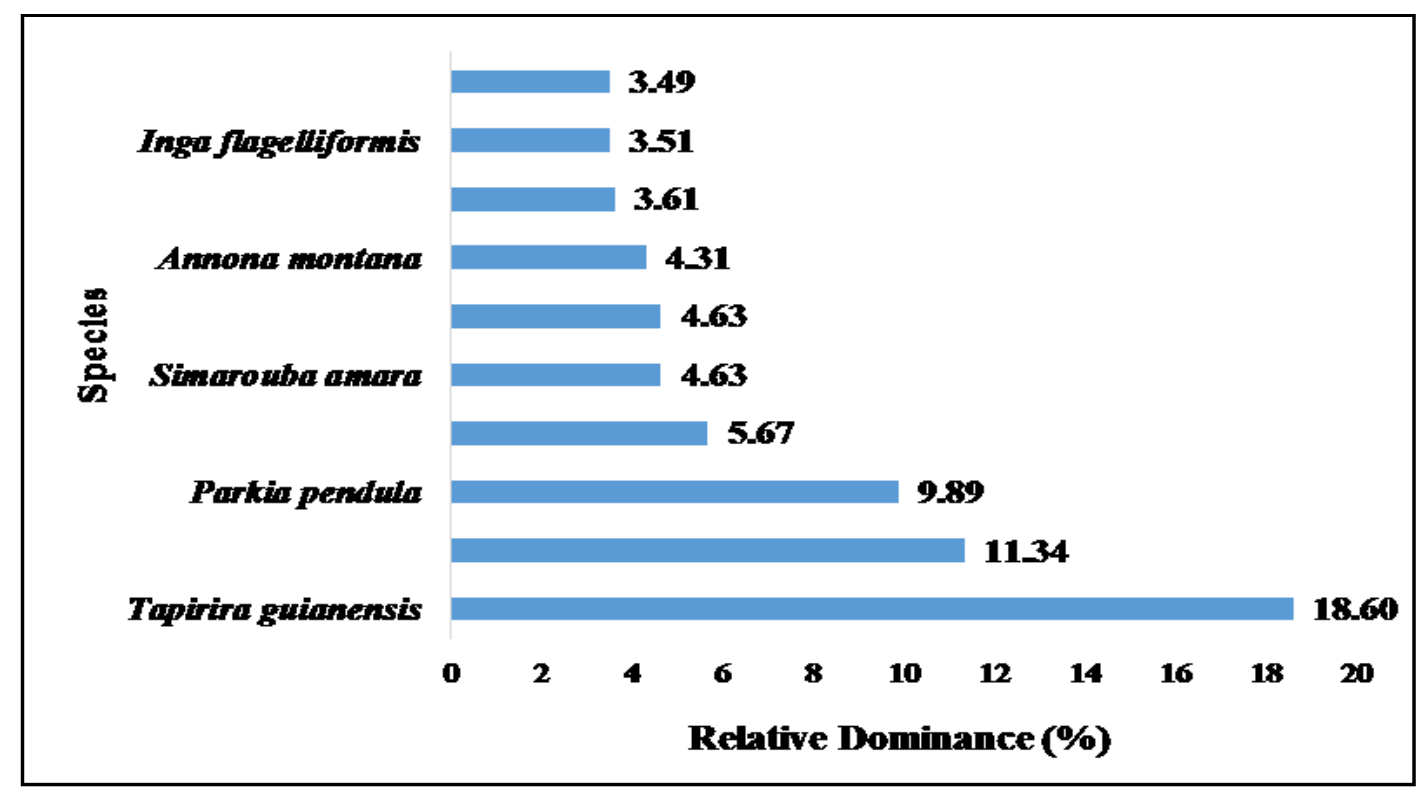

Figure 3 - Species with the ten largest values of Importance (VI), sampled at the springs of Córrego do Campo, Mata do Engenho Buranhém, in the municipality of Sirinhaém, Pernambuco

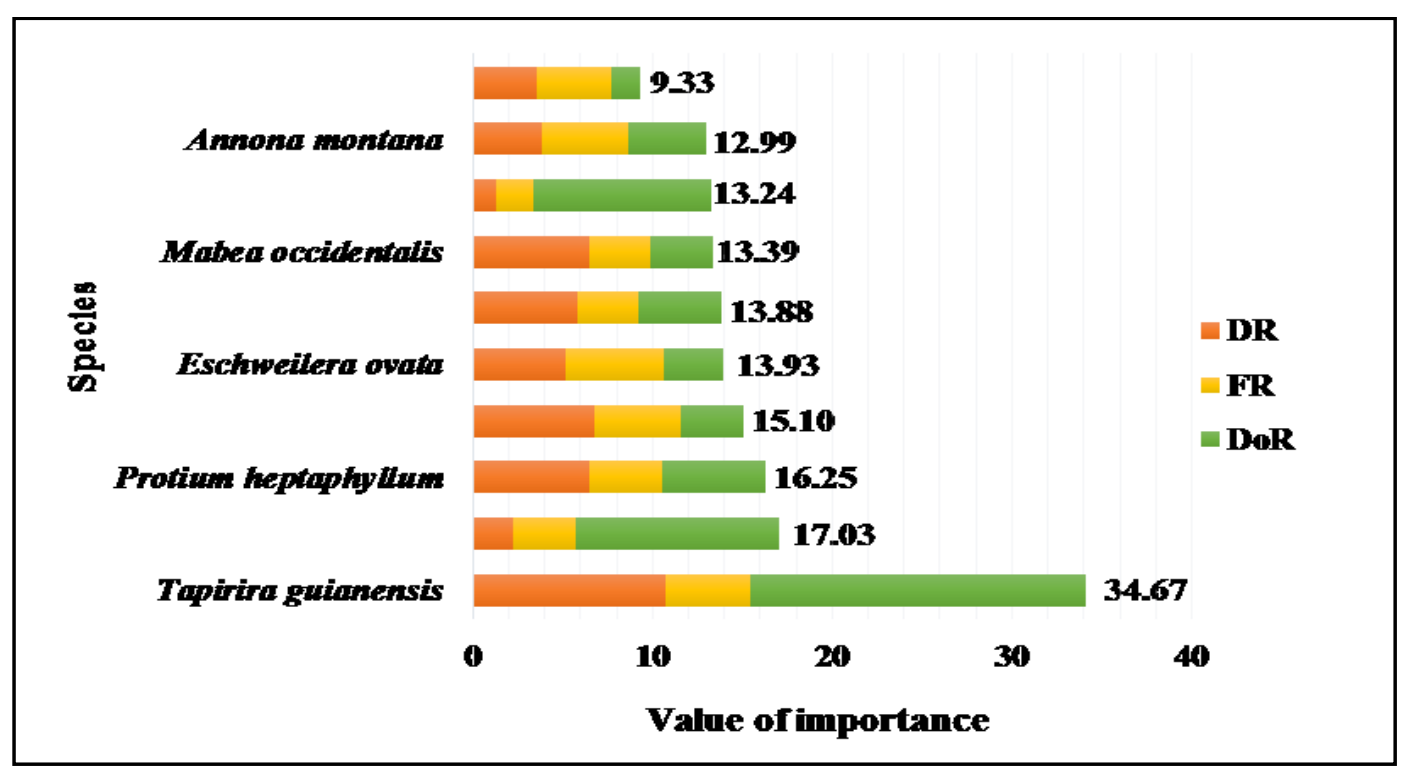

+ initial secondary), typical of secondary formations.

Among the species with high values of importance, Tapirira guianensis, Eschweilera ovata and Schefflera morototoni were sampled by Teixeira et al. (2010) in a floristic survey carried out in the Biological Reserve of Saltinho, Southern Coast of Pernambuco, demonstrating that they are common species for the region.

The highest coverage values (VC) were also obtained by Tapirira guianensis (29.28), Virola gardneri (13.61) and Protium heptaphyllum (12.14). The species Tapirira guianensis and Protium heptaphyllum were highlighted by the high values of relative density and relative dominance. The Virola gardneri species had low relative density, but it occupied the third position in the VC, due to the high diameter of its individuals, which influenced the relative dominance (DoR).

Regarding the state of conservation of the springs studied, taking into account the classification of Pinto et al. (2005), which classifies springs as conserved (presence of at least $50 \mathrm{~m}$ of natural vegetation in its surroundings, from the eye of water), disturbed (when it does not present $50 \mathrm{~m}$ of natural vegetation in its surroundings, but presents good state (high degree of disturbance, very little vegetation, compacted soil, presence of livestock, erosions and gullies), it is possible to infer that the Campo springs is classified as disturbed. 


\section{Final considerations}

The characteristics of the environment may be interfering with the predominance and distribution of the species observed. The studied springs can be characterized as disturbed, which may explain the low dominance of the individuals in the sampled area, since only $20 \%$ of the species that are among the ten most important ones occupy this position due to the high relative dominance value.

\section{Acknowledgement}

The authors express their gratitude to CNPq for the scholarship grant, to the Graduate Program in Forestry Sciences of UFRPE, to Usina Trapiche S/A, for the logistic support and permission to conduct the study. The authors also acknowledge researchers of the Herbarium IPA - Dárdano de Andrade Lima, for their support in the identification of the botanical material.

\section{References}

ALVARES CA, STAPE JL, SENTELHAS PC, GONÇALVES JLM, SPAROVEK G. Köppen's climate classification map for Brazil. Meteorologische Zeitschrift. 2013; 22 (6): 711-728.

APG IV. An update of the Angiosperm Phylogeny Group classification for the orders and families of flowering plants: APG IV. Botanical Journal of the Linnean Society. 2016; 181: 1-20.

BALBINOT R, OLIVEIRA NK, VANZETTO SC, PREDROSA K, VALERIO AF. O papel da floresta no ciclo hidrológico em bacias hidrográficas. Ambiência. 2008; 4 (1): 131-149.

BRASIL. Lei n. 12651, de 25 de maio de 2012. [Internet]. Brasília: Presidência da República,Casa Civil, Subchefia para Assuntos Jurídicos. Available from: http://www.planalto.gov.br/ccivil_03/_ Ato2011-2014/2012/Lei/L12651.htm. DATASUS [Internet]. Brasília: Presidência da República, Casa Civil [cited 2017 oct 01]. Legislação Presidência da República,Casa Civil - DATASUS. Available from: http://www4.planalto.gov.br/legislacao.

COSTA JÚNIOR RF, FERREIRA RLC, RODAL MJN, FELICIANO ALP, SILVA WC. Estrutura fitossociológica do componente arbóreo de um fragmento de floresta ombrófila densa na Mata Sul de Pernambuco, Nordeste do Brasil. Ciência Florestal. 2008; 18 (2): 173-183.
IBGE. Instituto Brasileiro de Geografia e Estatística: Manual Técnico da Vegetação Brasileira. Sistema fitogeográfico. Inventário das formações florestais e campestres. Técnicas e manejo de coleções botânicas. Procedimentos para mapeamentos. 2. ed. rev. ampl. Rio de Janeiro (Brasil): CDDI-IBGE, 2012. 276 p.

LOPES IS, FELICIANO AL, MARANGON LC, ALENCAR AL. Dinâmica da regeneração natural no sub-bosque de Pinus caribaea Morelet. var. caribaea na Reserva Biológica de Saltinho, Tamandaré - PE. Ciência Florestal. 2016; 26 (1): 95-107.

LOZINSKI MA, BALBINOT R, VENÂNCIO D, OLIVEIRA FILHO PC, SCHIRME WN. Diagnóstico das áreas de preservação permanente de nascentes na área urbana do município de Irati-PR. Floresta. 2012; 40 (1): 63-70.

MUEller DOMBois D, EllenberG H. Aims and methods for vegetation ecology. New York: John Wiley \& Sons; 1974. 547p.

OLIVEIRA NA, AMARAL IL. Florística e fitossociologia de uma floresta de vertente na Amazônia Central, Amazonas, Brasil. Acta Amazônica. 2004; 34 (1): 21-34.

OLIVEIRA NA, AMARAL IL, RAMOS MBP, NOBRE AD, COUTO LB, SAHDO RM. Composição e diversidade florístico-estrutural de um hectare de floresta densa de terra firme na Amazônia Central, Amazonas, Brasil. Acta Amazônica. 2008; 38 (4): 627-642.

OLIVEIRA DG, FERREIRA RA, MELLO AA, OLIVEIRA RSC, OLIVEIRA RSC. Análise da vegetação em nascentes da bacia hidrográfica do Rio Piauitinga, Salgado, SE. Revista Árvore. 2012: 36 (1): 27-141.

PINTO LVA, DAVIDE AC, BOTELHO AS, OLIVEIRAFILHO AT, MACHADO ELM. Distribuição das espécies arbóreo-arbustivas ao longo do gradiente de umidade do solo de nascentes pontuais da bacia hidrográfica do ribeirão Santa Cruz, Lavras, MG. Cerne. 2005; 11 (3): 294-305.

SANTOS HG et al. Sistema brasileiro de classificação de solos. 3. ed. Brasília: Embrapa; 2013. 353p.

SCARIOT A. et al. Efeitos da fragmentação sobre a biodiversidade: vegetação e flora. In: RAMBALDI DM, OLIVEIRA, DAS, editors. Fragmentação de ecossistemas: causas, efeitos sobre a biodiversidade e recomendações de políticas públicas. Brasília: MMA/SBF; 2003. p. 28-31.

SILVA ACC, PRATA APN, MELLO AA. Florística, fitossociologia e caracterização sucessional em um remanescente de Caatinga em Sergipe. Gaia Scientia. 2016; 10 (4): 01-14. 
SOARES CPB, PAULA NETO F, SOUZA AL. Dendrometria e inventário florestal, Viçosa: UFV; 2007. 276p.

TEIXEIRA LJ, FELICIANO AL, GALINDO ICL, MARTINS CM, ALENCAR AL. Relações entre a florística arbórea e características do solo em um fragmento de Floresta Atlântica, Tamandaré - PE. Revista Floresta. 2010; 40 (3): 625-634.

\section{Contribuição dos autores}

Roseane Karla Soares da Silva

Redigiu o trabalho r realizou uma revisão substancial.

Ana Lícia Patriota Feliciano

Contribuições substanciais para a concepção do trabalho.

Luiz Carlos Marngon

Contribuições substanciais para a concepção do trabalho.

Rosval Barros de Andrade Lima

Redigiu o trabalho e realizou uma revisão substancial.

Fernando José Freire

Análise e interpretação de dados. 